\title{
Modelización financiera mediante modelos híbridos Arima-Garch: evidencia para Argentina
}

\author{
Financial Modeling with Hybrid Arima-Garch Models: \\ Evidence for Argentina \\ Modelização financeira por meio de modelos híbridos \\ Arima-Garch: Evidência para Argentina \\ Tomás Francisco Larre \\ Universidad de Buenos Aires, \\ Buenos Aires, Argentina. \\ E-mail: tflarre@gmail.com \\ Joaquín Auza \\ Universidad de Buenos Aires, \\ Buenos Aires, Argentina \\ E-mail: auzajoaquin@gmail.com
}

Fecha de recepción: 29/10/2019

Fecha de aceptación: 06/12/2019

\section{Resumen}

El propósito de este trabajo es modelizar el patrón de volatilidad presente en la serie histórica de retornos del principal índice del Mercado de Valores de Buenos Aires (MERVAL) entre el 1 de enero de 2013 y el 6 de junio de 2016, empleando la familia de modelos híbridos ARIMA-GARCH. Se realiza un estudio de literatura econométrica enfocada a la modelización de índices bursátiles para otras economías emergentes. Se verifican las condiciones para el empleo de esta familia de modelos. El análisis confirma la presencia de asimetría y efecto apalancamiento por los que se utilizan modelos asimétricos E-GARCH y GJR-GARCH, tanto con distribución Normal como con distribución $t$ - Student. Se estiman de forma iterativa modelos para distintos órdenes de las especificaciones mencionadas. Para la selección de modelos dentro de la muestra se recurre al Criterio de Información de Schwarz. Se somete los modelos estimados a una secuencia de pruebas de hipótesis a fin de garantizar el cumplimiento de las siguientes propiedades: la captura de todo componente sistemático del proceso, inexistencia de sesgo de signos y magnitud y estabilidad de los parámetros. Posteriormente, se hacen observaciones fuera de la muestra con el fin de evaluar su poder

Palabras clave

- volatilidad

- apalancamiento

- heteroscedasticidad condicionada de pronóstico. Finalmente, se constata que el E-GARCH $\sim t(1,1)$, con modelos de media ARMA $(2,0)$ y ARMA $(2,1)$ resulta superior dentro de la muestra y su capacidad predictiva no resulta significativamente inferior a la de otros modelos estimados. 
Keywords

- Volatility

- Leverage

- Conditional Heteroscedasticity

\begin{abstract}
The aim of this work is to model the volatility pattern during the historical stock return of the most important index of the Buenos Aires Stock Exchange (MERVAL) from January 1 of 2013 to June 6 of 2016, using the family of hybrid Arima-Garch models. The study is based on econometrics bibliography with a focus on stock index modeling for other emerging economies. The conditions to employ this family of models are verified. The analysis confirms the existence of asymmetry and a leverage effect, which is the reason why the asymmetric E-Garch and GJR-Garch models are used, with both normal and student's $t$ distributions. For different orders of the aforementioned specifications, the models are repeatedly estimated. For the selection of models to use in-sample, the Schwarz information criterion is opted for. The estimated models are subject to hypothesis testing in order to guarantee compliance with the following properties: each systematic component of the process is taken into account, there are no bias of indicators or magnitude, and there is parameter stability. Then, the out-of-sample forecast performance is tested. Finally, it is observed that the E-Garch $\sim t(1,1)$, with ARMA $(2,0)$ and ARMA $(2,1)$ models, is superior in-sample and its forecasting performance is not significantly inferior to the other estimated models.
\end{abstract}

\section{Resumo}

0 objetivo deste trabalho é modelizar 0 padrão de volatilidade presente na série histórica de retornos do principal índice do Mercado de Valores de Buenos Aires (MERVAL) entre 01 de janeiro de 2013 e 06 de junho de 2016, utilizando a família de modelos híbridos ARIMA - GARCH. Realiza-se um estudo de literatura econométrica focada à modelização de índices bursáteis para outras economias emergentes. Verificam-se as condições para 0 uso desta família de modelos. A análise confirma a presença de assimetria e efeito alavancagem pelos que se utilizam modelos assimétricos E-GARCH e GJR - GARCH, tanto com distribuição Normal quanto com distribuição $t$ - Student. Estimam-se de forma iterativa modelos para diferentes ordens das especificações mencionadas. Para a seleção de modelos dentro da amostra recorre-se ao Critério de Informação de Schwarz. Submete-se os modelos estimados a uma sequência de provas de hipótese a fim de garantir 0 cumprimento das seguintes propriedades: a captura de todo componente sistemático do processo, inexistência de sesgo de signos e magnitude, e estabilidade dos parâmetros. Posteriormente utilizam-se observações fora da amostra com o fim de avaliar seu poder de prognóstico. Finalmente constata-se que $0 \mathrm{E}-\mathrm{GARCH} \sim t(1,1)$, com modelos de meia ARMA $(2,0)$ e ARMA $(2,1)$, resulta superior dentro da amostra e sua capacidade preditiva não resulta significativamente inferior à de outros modelos estimados. 